\title{
YNACA ECO Y JOSÉ CEMÍ: UNA LECTURA SOBRE LA METAFÍSICA SEXUAL LEZAMIANA EN PARADISO Y OPPIANO LICARIO ${ }^{1}$
}

\author{
Edinson Aladino \\ Benemérita Universidad Autónoma de Puebla \\ edialad@hotmail.com
}

\section{RESUMEN / ABSTRACT}

En la novelística de José Lezama Lima el asunto del erotismo cuenta con un vasto horizonte temático. La búsqueda de una vía copular erigida bajo los preceptos androginales es uno de los puntos que se desarrolla en Paradiso y se concreta en Oppiano Licario por medio de las relaciones sexuales entre Ynaca Eco y José Cemí. En este artículo se examina el tema de la cópula asociado con la androginia platónica a partir de estos dos personajes, en los que se fundamenta la concepción de la metafísica sexual lezamiana.

Palabras Clave: Paradiso, Oppiano Licario, erotismo, sexualidad, androginia.

In José Lezama Lima's novelistic work the issue of eroticism counts with a vast thematic horizon. The search of a coupling way erected under androgynous precepts is one of the main points developed in Paradiso and takes shape in Oppiano Licario by means of sexual relations between Ynaca Eco and José Cemí. This article examines the theme of coupling associated with the platonic androgyny in these characters, in whom is based Lezama's conception of sexual metaphysics.

KEYWORDS: Paradiso, Oppiano Licario, eroticism, sexuality, androgyny.

1 Este ensayo fue presentado en el Congreso Internacional de Literatura Hispánica, realizado en Córdoba, Argentina, en agosto de 2014. 
Es justo en el terreno del erotismo donde se libran nuestras últimas batallas metafisicas. Peter Sloterdijk, Experimentos con uno mismo. La cópula es el más apasionado de los diálogos. José Lezama Lima

De los diversos temas que abarca la novelística de José Lezama Lima, uno de los más complejos es, sin duda, la sexualidad. En las presentes páginas se analiza y expone la cuestión de la metafísica sexual que se establece en Paradiso y Oppiano Licario a través del encuentro de dos personajes: Ynaca Eco y José Cemí. El joven Cemí defiende una concepción del sexo mediante una teoría de la androginia ${ }^{2}$, por la que el Eros Cognoscente ${ }^{3}$ convierte la sexualidad en una práctica gnoseológica, una revelación, en la que se advierte el reconocimiento de algo sabido de manera previa, a través de un darse y poseerse en el contacto directo con la otra mitad corporal reencontrada. La cópula se convierte en un diálogo ontológico por excelencia, donde el fondo primordial del ser puede encontrarse a sí mismo, puede adquirir el conocimiento de sí mismo. Esto sienta las bases del desarrollo de un mito elemental para atravesar el espejo propio en un intento por reunir lo que fue escindido. Lo que nos pone en relación con una metafísica en la que se privilegia la Aletheia de los griegos, la desocultación del ser, que propone quitar el velo de aquello

2 Es claro que el neoplatonismo tiene que ver con las corrientes filosóficas alejandrinas en el siglo III, llevadas a cabo por Amonio Saccas y Plotino, declarados herederos de la cultura helénica por antonomasia (Reyes 200). Igualmente, en el Renacimiento italiano se recupera gran parte del pensamiento filosófico de Platón y se lo incorpora a la visión humanística de las artes, con Marsilio Ficino y Pico della Mirándola (Gombrich 102). Sin embargo, Lezama Lima no hace parte de estas corrientes filosóficas y sería errado enmarcarlo dentro de esta línea continua. Él retoma el mito de la androginia de Platón y lo transfigura en sus dos poéticas noveladas por medio del discurso que tiene José Cemí acerca de la sexualidad. Es decir, no se reproduce la misma teoría platónica de los andróginos, sino que se le adhieren nuevas significaciones ontológicas y gnoseológicas al lezámico modo. Esto es, tomar nuevamente la tradición, no como modelo estable, sino como presente cambiante, para reactualizarla a través de nuevas lecturas suscitadas por el barroco americano (Ortega 510). Aspecto que veremos más adelante.

El Eros Cognoscente es el motor del aprendizaje de José Cemí, que lo lleva a lo largo de la novela a emprender la búsqueda de su formación poética, que se concreta con el encuentro de su maestro Oppiano Licario en los últimos capítulos de Paradiso. 
que es obvio para nosotros y rescatar su presencia originaria. La sexualidad, en este sentido, se constituye como un acontecimiento que dispone una experiencia de integración, de apertura unitiva.

\section{JOSÉ CEMÍ Y SU TEORÍA DE LA ANDROGINIA}

Para introducirnos en la temática de la metafísica sexual lezamiana, primero hay que tener en cuenta que este aspecto se desarrolla en Paradiso y se concreta en Oppiano Licario, por medio de la cercanía gradual entre Ynaca Eco y José Cemí. Lo que nos lleva a observar la experiencia progresiva de éste último y su incursión en el entramado de la obra, para comprender su postura frente al sexo y posteriormente su encuentro con Ynaca.

En el transcurso de Paradiso vemos la evolución física e intelectiva del personaje central, aunque Lezama insistía en que José Cemí no es el protagonista de sus novelas, sino un hilo conductor en el que se encarna (y en el que se personifica) su visión del mundo ${ }^{4}$. En una entrevista que le hace Jean-Michel Fossey al respecto, el autor cubano responde:

Me encontré que la poesía bullía, hervía, como azarosa de quererse convertir en otro mundo; cada metáfora se iba convirtiendo en un personaje, cada imagen en una situación en la novela en sí y entonces me fui transportando, un poco mágicamente, como en la alfombra de Bagdad, de la poesía a la novela. Pero en cuanto uno penetra en las páginas de Paradiso nos damos cuenta de que estamos en la misma raíz, en la misma de la poiesis, como decían los griegos, de la creación del mundo respirante, afanosos de transformar lo inorgánico en orgánico, lo más lejano en cercano y todo pletórico de un mundo que se agita y aspira a vivir (13).

\footnotetext{
4 Cemí es una palabra taína de una de las culturas originarias reconocidas en Cuba a la llegada de Colón. Los cemíes son ídolos modelados en barro, tallados en concha o en piedra. De manera que Lezama se sirve de sus personajes para recrear su propio universo: "Un trasunto de mi personalidad aparece con el nombre de José Cemí, que es fácil para todo cubano su desciframiento: Cemí, un ídolo, una imagen (...) Una de las obsesiones mías ha sido la imagen, por eso uno de los personajes, si no el central por lo menos el impulsador central de la novela, se llama Cemí" (E. Lezama 64).
} 
Paradiso puede resumirse como la narración de las experiencias de José Cemí, con su familia, en la universidad, con sus amigos Fronesis y Foción, y con el que será finalmente su maestro, Oppiano Licario. Todo ello enmarcado en un contexto que abarca la historia de Cuba desde mediados del siglo XIX hasta las primeras décadas del siglo XX. Los primeros capítulos nos muestran la etapa placentaria de Cemí, el espacio familiar y la infancia; en una segunda parte, la narración se centra en la adolescencia, los años escolares, la vivencia en la universidad y el hallazgo de la amistad; por último, tenemos la apertura del joven, iniciado por Oppiano Licario, en el conocimiento a través de la imagen. José Cemí, como lo anota Eloísa Lezama Lima, es un Wilhelm Meister habanero, que representa el aspecto sagrado de la aventura total del hombre 5 (66).

Paradiso es un viaje iniciático en la radiación de las ideas y el conocimiento. En esa búsqueda integral del hombre, lo sexual no se constituye como un espacio desprovisto de significación. El mismo Lezama comenta:

Paradiso es una totalidad y en esa totalidad está el sexo. En determinado momento del desarrollo de José Cemí ocurre el despertar genesíaco. Ahí se recupera una libertad cuya aparición parece que resintió a algunos acostumbrados a la hoja de parra y a aquellos, pintoresastres de los que se rieron los renacentistas, obligados a tapar las castas desnudeces de Miguel Ángel en La creación del mundo, pero para mí, con la mayor sencillez, el cuerpo humano es una de las más hermosas formas logradas (Simón 35).

El illo tempore de la narración nos sitúa en el capítulo VIII, donde ocurre el "despertar genesíaco" de José Cemí. Pero la iniciación sexual de este adolescente -en dicho apartado- solo ocurre como espectador. El capítulo VIII no narra ninguna experiencia personal de Cemí, ni tampoco refiere un

$5 \quad$ Al igual que Las tribulaciones del estudiante Törless (1906) de Musil, Retrato del artista adolescente (1916) de Joyce o La montaña mágica (1924) de Mann, la obra de Lezama presenta aspectos de la novela de formación, de aprendizaje, lo que se conoce como Bildungsroman. Asistimos a la formación integral de José Cemí, de la transición de su niñez a la edad adulta. Sin embargo, una de las fuentes de donde toma acopio el autor para direccionar las distintas fases evolutivas del personaje central es la tradición órfica: la creencia en la experiencia poética como sendero de conocimiento. Por eso los acontecimientos de la vida de José Cemí, como joven aprendiz de poeta, se van articulando progresivamente hasta desembocar en el ingreso "a una realidad definida por la búsqueda de la poesía absoluta" (Ortega 510). 
solo acto de onanismo por parte de él, como podría esperarse en episodios de adolescencia. El personaje descubre la apertura a la sexualidad solo como testigo, a través de inusitados pasajes eróticos de colegio, en donde se privilegia el cuerpo, los sentidos, el placer orgánico y el diálogo amatorio con cualquier signo (Driver 32).

José Prats Sariol arguye que la actitud pasiva del personaje central en el capítulo VIII, se debe a que "la heterodoxa catolicidad de Lezama no permite que la llama del azufre queme a Cemí" (662). No obstante, resulta más plausible interpretar aquella actitud como un retraimiento de ese plano libidinal, porque el adolescente protagonista desea el encuentro de un contacto transfigurativo. El desborde sexual sin ninguna intelectualización del eros es algo que le queda vedado a José Cemí, debido a su condición de poeta guardián de la imagen y a su búsqueda de una sexualidad mítica y metafísica, en la que se recuperan los mitos androginales y en la cual el individuo "se proyecta sobre los misterios complementarios" (Lezama, Paradiso 268). Es la idea de un eros que actúa no solo como fuerza germinadora, sino como vivencia extraordinaria de unión cósmica de los contrarios. Algo que José Cemí experimentará en Oppiano Licario.

En el capítulo IX encontramos al joven protagonista en la Universidad de La Habana. Allí empiezan los encuentros de Cemí con Fronesis y Foción, que conforman la tríada pitagórica ${ }^{6}$. En esos encuentros -donde se entregan a sus diálogos eruditos- ocurre el largo debate sobre la homosexualidad, que es suscitado por la historia de Baena Albornoz. Lo que nos interesa observar es que el sexo en el capítulo IX solo cuenta para Cemí en la conversación de las ideas. Sus amigos, con polaridad de opciones (Fronesis-Lucía, Foción-El pelirrojo), sí entran en el territorio orgánico de la cópula. Esto se debe a la concepción que tiene el personaje central respecto a la sexualidad, debido a que sus dos compañeros albergan otras ideas sobre el asunto, que vendrían a estar más del lado de la homosexualidad o la afirmación heterosexual.

\footnotetext{
Como ya lo vimos, el mismo Lezama refiere que cada personaje corresponde a una metáfora, representa un símbolo. Eloísa Lezama Lima advierte: "La tríada amistosa, platónica, formada por Cemí, Fronesis y Foción, la trinidad, el tres pitagórico, representan tres símbolos esenciales: Foción es la autodestrucción, el que no tiene meta y cuyo final será dar la vuelta al árbol fálico, ya loco, buscando un orden en su desorden; Fronesis es la eticidad, el deseoso que busca los orígenes, busca a su madre; Cemí, instinto, razón y redención por la poesía" (67).
} 
En este largo debate, Cemí da cuenta de su visón acerca del sexo y refiere su teoría de la androginia. El primero que abre la discusión es Ricardo Fronesis. Para él, la homosexualidad hace parte de la memoria ancestral del hombre. Todo es comprendido a partir de un estado de inocencia en que el sujeto busca su igual, su semejante, para establecer su sexualidad:

El hombre de las eras fabulosas tendía a reproducirse en la hibernación, ganaba la sucesión precisamente en la negación del tiempo. El falo se hacía árbol o en la clavícula surgía un árbol, de donde como un fruto se desprendía la criatura. El recuerdo de esas eras fabulosas se conserva en la niñez, en la inocencia de la edad de oro, cuando es casi imposible distinguir cualquier dicotomía (...) El niño que después no es adolescente, adulto y maduro, sino que se fija para siempre en la niñez, tiene siempre tendencia a la sexualidad semejante, es decir, a situar en el sexo la otredad, el otro semejante a sí mismo. Por eso el Dante describe en el infierno a los homosexuales caminando incesantemente, es el caminar del niño para ir descubriendo lo exterior (Lezama, Oppiano Licario 263-264).

El estado de inocencia al que se hace referencia es la niñez, en la que aún no hay cabida, según el personaje, para diferenciaciones o distinciones acerca de cualquier dicotomía sexual. Por lo cual, las relaciones entre sujetos del mismo sexo se definen en este caso como la manifestación de una memoria ancestral supeditada a un estado de inocencia. Lo que arguye Fronesis coincide con las ideas freudianas sobre el tipo narcisista en la elección de objeto, según las cuales el homosexual no elige a otro de su mismo sexo, sino a sí mismo bajo el reflejo de otro (Freud 7-37). También hay que anotar que este personaje califica la homosexualidad como una especie de desvío sexual (Lezama, Oppiano Licario 277-278); es decir, que para él estas relaciones son "anormales", puesto que lo "normal" vendría a ser las relaciones heterosexuales. Esto nos aclara el punto de vista y la posición de Ricardo Fronesis, dado que él representa la afirmación de la "normalidad" heterosexual.

Foción, por su parte, arremete contra su amigo con cierto desenfado y utiliza argumentos históricos, culturales e incluso teológicos para dar su visión de la homosexualidad:

Tú sigues creyendo (...) que el homosexualismo es la excepción, un vicio traído por el cansancio, o una maldición de los dioses (...) El hombre ha asimilado, lo mismo da que sea un mito de primitivo o un laberinto del período de las culturas, las dos cosas, las semejanzas 
o las heterogeneidades, los Dióscuros o los ángeles buscando a las hijas del hombre (...) Pero ya desde el siglo V antes de Cristo, los más frecuentes temas taoístas eran el espejo, el andrógino, el Gran Uno (...) Es muy difícil que un Sócrates que se mueve en una circunstancia donde el homosexualismo no era una excepción, argumente en el sentido de la justificación, pues no se sentía réprobo, ni creía haber quebrantado ninguna ley (265-266).

Foción arguye que el ser humano a lo largo de la historia ha asimilado las semejanzas y las heterogeneidades dentro de su esfera sexual. Lo uno y lo otro, de acuerdo con esta posición, han estado en perpetuo diálogo, pues la relaciones eróticas entre individuos del mismo sexo son tan antiquísimas como las relaciones heterosexuales. Aquí se establece un punto de vista que considera la homosexualidad tan normal y originaria como la relacionas eróticas entre individuos de diferente sexo.

Seguidamente, José Cemí interviene en el debate trazando una teoría de la androginia que apela "a la sustancia que recuerda, los mitos previos al dualismo de los sexos, para que lleguemos a ser lo que no éramos" (282). Lo que vendría a completar, en cierto modo, la postura de Foción, que prestigia la homosexualidad o niega su carácter perverso o anómalo. Sin embargo, lo que postula Cemí va más allá del espejo de Narciso, va más allá de una defensa o una descalificación de la homosexualidad. Este debate da pie para que el joven protagonista plantee su concepción sobre la sexualidad, en donde la cópula se constituye como una plena experiencia ontológica (Driver 34-35). La metafísica del sexo defendida por Cemí concibe esta práctica como la más auténtica actividad cognoscitiva del hombre, como el más profundo modo de intelección, mediante el cual el ser accede al reconocimiento de sí mismo:

Desde que el ser surgió en nosotros, en la cultura griega no se altera por el andrógino o por la diada universal, que hay una categoría superior al sexo, que recuerda lo mitos androginales o al que se proyecta sobre los misterios complementarios. Pero como hubo épocas anteriores a la aparición del ser en los griegos, y como casi toda la filosofía contemporánea se dirige a barrenar el ser aristotélico, podemos todavía buscar el juego de las imágenes sexuales en los muslos de oro, las orejas paridoras, las derivaciones de la creación excesiva del escita con su corcel (...) Apenas la imagen logra un punto de apoyo, la tierra vuela encontrando un centro en todas partes, logrando ese punto surge la esfera, ya tenemos un cosmos cuyo centro es la imagen, flotando 
en el aceite de la reminiscencia y en las brumas de un devenir que se mueve tan sólo en las llanuras de la cantidad como abstracción (282).

Pero la discusión es interrumpida por una gresca estudiantil y el episodio concluye, según Cintio Vitier, "dentro de la tradición goethiana de una precisa fantasía perceptiva, con una exaltación y apoteosis del culto a la fecundidad heterosexual" (13). Lo que resalta Vitier es una alucinación de Cemí, que vislumbra un desfile de la antigüedad greco-latina, encabezado por un falo gigantesco rodeado de vulvas de tamaño proporcional, que parece resumir su actuación en el debate y cierra el capítulo de manera inusitada.

El Eros que postula José Cemí se define en la conjunción heterosexual, en el diálogo transgresor de los límites individuales que logra anular la distancia con el otro que nos completa. El propio Lezama anota algo respecto: "La cópula es el más apasionado de los diálogos (...) Es el apoyo frente al horror vacui" (Simón 35). Dicho diálogo tiene su origen en un impulso que intenta contrarrestar una carencia inicial: la búsqueda de la mitad ausente. El deseo, por consiguiente, es el significante de lo incompleto, que empuja a celebrar una ceremonia de reconocimiento en la unión de los opuestos. Emilio Armas resume esto como la presencia de un "eros asumido en una dimensión que trasciende lo específicamente erótico y aun sensual para volcarse en la realidad como un vertimiento posesivo del ser" (20).

La teoría de la androginia la encontramos expuesta en El Simposio (Banquete) o de la erótica, diálogo filosófico escrito por Platón. Allí Aristófanes evoca el mito de ese ser completo del que, por desgracia, solo somos la otra mitad. Tal mito cuenta que el ser humano formaba un ser doble, compuesto por ocho miembros, dos caras y con sexos alternativamente idénticos o diferentes. Pero estos seres fueron desligados de sus mitades. Por tanto, el amor es siempre la búsqueda de la otra mitad, es decir, la aspiración de recuperar la unidad perdida:

La causa de esto es que nuestra naturaleza primitiva era una, y que éramos un todo completo, y se da el nombre de amor al deseo y prosecución de este antiguo estado. Primitivamente, como he dicho, nosotros éramos uno; pero después en castigo de nuestra iniquidad, nos separó el dios como los arcadios lo fueron por los lacedemonios (...) Sea lo que quiera, estoy seguro de que todos seremos dichosos, hombres y mujeres, si, gracias al amor, encontramos cada uno nuestra mitad, y si volvemos a nuestra naturaleza primitiva (364-365). 
El Eros del que habla Aristófanes tiene que ver con la restitución de una naturaleza originaria, la conjunción de una unidad, de una totalidad del ser: la vuelta del andrógino. Si nos adentramos en la biblioteca de José Cemí, vemos que gran parte de su metafísica sexual está permeada por las ideas del filósofo griego:

\begin{abstract}
Al igual que Fronesis, la apasionada lectura de Platón lo había llevado a polarizar su cultura. Las grandes rapsodias del Fedro y el Fedón lo llevaban a esa mezcla de exaltación y de lamento que constituyen el amor y la muerte en la fulguración de su conjunto (...) En el Charmides encontraría la seducción de las relaciones entre sabiduría y memoria. "Sólo sabemos lo que recordamos", era la conclusión délfica de aquella cultura, que andando los signos encontraría en Proust la tristeza de los innumerables seres y cosas que mueren en nosotros cuando se extinguen nuestros recuerdos. Y los meses inolvidables de su adolescencia, transcurridos en el Timeo, que le enseñaba el pitagorismo y las relaciones entre los egipcios y el mundo helénico. Y el aparente descanso ofrecido por el Simposio, engendrando los mitos de la androginia primitiva y la búsqueda de la imagen en la reproducción y en los complementarios sexuales de la Topos Urano y de la Venus celeste (Lezama 349-350).
\end{abstract}

Lo que se nos muestra a partir de la biblioteca de Cemí, es el acopio de la cultura griega bajo los presupuestos de una relectura de la tradición, de asumirla de un modo activo bajo un:

Simpathos por la sensibilidad creadora contemporánea en sus dos fases, de reavivamiento del pasado como de búsqueda de un desconocido (...) Era la prueba de una recta interpretación del pasado, así como la decisión misteriosa de lanzarse a la incunnabula, pero eso era más bien debido a las lecturas del pasado creador, que habían tenido que sufrir un riesgo, interpretar un desconocido y lanzarse a perseguir elementos aún no configurados (350).

Lezama, en su último ensayo "La expresión americana", escribe algo paralelo a esto cuando habla de la acción creadora en el momento de interpretar el pasado, realizando un reavivamiento de éste mismo y a partir de allí lanzarse hacia la búsqueda de lo nuevo. Desde esta perspectiva la tradición no es un ente cristalizado, estable o fijo; sino un "presente cambiante" (Ortega 511), que a través de la apuesta del barroco -al lezámico modo- se reordena en 
un diálogo entendido como saber crítico, creador: "nuestro ente de análogo cultural presupone la participación, sobre un espacio contrapunteado del sujeto metafórico. Pudiéramos tal vez decir que ese sujeto metafórico actúa como el factor temporal, que impide que las entidades naturales o culturales se queden galée en su estéril llanura" (Lezama, La expresión 54). El autor cubano nos advierte que la cultura occidental también nos pertenece, hace parte de nuestro pasado, y el manejo que hagamos de ésta nos hará igualmente libres en ella. La recuperación de la tradición radica en una toma de posición integradora, para reconstruir y reconducir nuevas lecturas mediadas por el "protoplasma incorporativo del americano" (177), sin perder de vista la función de crear nuevos mitos. Aspecto que Lezama ya apuntaba de manera más sintética en las "Playas del árbol", pequeño extracto que hace parte del ensayo Tratados en La Habana: "Lo propio del sofista, según Aristófanes, es inventar razones nuevas. Procuremos inventar pasiones nuevas, o reproducir las viejas con pareja intensidad" (512).

El erotismo del capítulo VIII de Paradiso se configura bajo el signo de lo indómito, del desenfreno, del impulso montaraz, en el que no hay cabida para una relación erótica transfigurativa o trascendente. El joven poeta se resguarda de este eros y espera la llegada de una instancia sexual reveladora. Pues como lo demarca la misma novela, sabía que:

El conformismo en la expresión y en las ideas tomaba en el mundo contemporáneo innumerables variantes y disfraces, pues exigía del intelectual la servidumbre, el mecanismo de un absoluto causal, para que abandonase su posición verdaderamente heroica de ser, como en las grandes épocas, creador de valores, de formas, el saludador de lo viviente creador y acusador de lo amortajado en bloques de hielo, que todavía osa fluir en el río de lo temporal (350).

En el capítulo IX, José Cemí hace énfasis en la concepción de la cópula como experiencia ontológica del ser y, asimismo, deja por sentado su metafísica sexual, en la que recupera el mito previo al dualismo de los seres. Dicha recuperación no es una glosa fragmentaria en donde vemos sin ninguna fundamentación el desenvolvimiento erudito del personaje central; por el contrario, asistimos a la reactualización de una instancia mítica y metafísica de la sexualidad. No coexiste en la asunción de la androginia postulada por Cemí la conjunción de un romanticismo unidireccionado hacia la búsqueda de una simple unión de los contrarios, sino la creación de un espacio transfigurador, la cópula como elemento de apertura para debatir en ella -a través del Eros cognoscente- un 
despliegue ontológico y epistémico en el que Cemí reconoce lo que le falta: la visión que unifica la imagen?

No obstante, es en la segunda novela, la continuación de Paradiso, en donde se desarrolla el sistema de ese "Eros cognoscente". Oppiano Licario es el que guía al joven Cemí a la concreción de dicha experiencia. Licario es un misterioso personaje que se inserta en las páginas de Paradiso sin la habitual identificación de nombre, historia y circunstancia. Lezama señala que:

Oppiano viene de Oppianus Claudium, un senador estoico de la época romana y Licario de "l'icare", el Ícaro que intenta la infinitud, que intenta lo imposible; y de ahí formé ese androide, ese monstruosillo que es Oppiano Licario, una especie de diamante, de ente supremamente intelectualizado, arquetipo que busca como la ciudad tibetana, el eros de la lejanía, la tierra donde se confunde lo real con lo irreal, lo que ya los antiguos llamaban la orplide, una lontananza ideal, la lejanía de algunos románticos alemanes (E. Lezama 70).

Oppiano Licario aparece -en la primera novela- cuando no se le espera, siempre en momentos cruciales, dando a cada episodio un significado litúrgico, simbólico. En el capítulo V es el anónimo "consejero latino" que conduce a Alberto Olaya a su iniciación sexual; su segunda aparición tiene lugar momentos antes de la muerte del Coronel, padre de Cemí; la tercera, en el ómnibus mágico del capítulo XIII; y al final de la obra, después de un proceso gradual de acercamiento, Licario preside otro rito sagrado en el espacio mágico de su habitación: inicia a José Cemí en el "ritmo hesicástico" de la poesía.

La obra misma define el "ritmo hesicástico" como equilibrio anímico, en oposición al "ritmo sistáltico", que tiene que ver con las pasiones tumultuosas. Ambos conceptos hacen parte de la tradición musical de los pitagóricos. Aunque, según Cintio Vitier, hesiquiastas o hesicastas se llamaban también los seguidores de una corriente mística de la Iglesia Oriental entre los siglos XI y XIV, que con su sistema de meditación (mirándose fijamente el ombligo, donde suponían concentradas todas las fuerzas del alma) se

\footnotetext{
Cemí es el poeta que alcanzó el conocimiento a través de la imagen en Paradiso, pero necesita la visión de Ynaca Eco para alcanzar el contorno de la poesía absoluta. Punto que se concreta en la segunda novela, Oppiano Licario, en la cual Ynaca necesita, a su vez, de la sabiduría poética de Cemí para afianzar su desarrollo como visionaria.
} 
proponían la percepción sensible del sumo bien (523-524). Licario ofrece a Cemí la sofrosine, el justo equilibrio, o como los monjes de Constantinopla, el empeño en la experiencia sensorial de la poesía. Ese "ritmo hesicástico" ha ido configurándose en Cemí por la suma gradual de todas sus experiencias, que se cristaliza en el encuentro con su maestro al final de la novela.

\section{LA LLEGADA DEL DESEO: EL SIMPATHOS DE LA VÍA UNITIVA}

Las relaciones entre Ynaca Eco y José Cemí tienen un proceso escalonado. El contacto entre ellos sucede bajo ciertos prolegómenos. La misión de Oppiano Licario en Paradiso, antes de morir, había sido guiar a Cemí en la sabiduría; ahora debe guiarlo (desde la eternidad) hacia su hermana. Después de la muerte de su mentor, José intenta hablar con Ynaca. La primera escala de la búsqueda es la vivienda de sus encuentros con el maestro: la calle de Espada 615. Las distintas etapas de esta búsqueda están permeadas por la presencia sideral de Licario. Luego de recorrer ciertos tramos y por medio de un "azar concurrente", sucede el reencuentro de los personajes: "se habían conocido en la casa de los muertos y coincidían de nuevo al entrar en el castillo, convertido ahora en una biblioteca" (Lezama, Oppiano 286).

Los preliminares de la fusión entre Ynaca y Cemí ocurren en el Castillo de la Fuerza de La Habana, lugar enormemente significativo para Lezama, ya que en Paradiso se anunciaba como un centro imantado, un escenario para encuentros trascendentales. Ynaca, por su parte, le revela a Cemí que ese encuentro obedece a la voluntad de Licario:

Licario me decía con frecuencia: él tiene lo que a nosotros nos falta. Después añadía: yo lo he conocido demasiado tarde, la muerte está cerca, pero tú debes conocerlo en la juventud de los dos. Pero nunca nos dijo qué era lo que nos faltaba y qué era lo que usted tenía. Conocerlo a él será tu mejor fuente de conocimiento, me repetía. Al morir Licario creyó que su vida se había logrado por dos motivos: porque al fin lo había conocido a usted y porque nosotros dos nos conoceríamos. Ahora los tres podemos estar contentos (...) Por Licario sé, y eso es para mí como una orden sagrada, que lo que me falta sólo podré conocerlo en usted (293-294).

La confesión es reveladora. El encuentro estaba previsto por Oppiano Licario, que sirve de guía, de vehículo, para que se propicie el nexo entre los dos. 
Dimensión literal y alegórica que Lezama otorga a los personajes a través de una lenta convergencia en la obra. Ynaca Eco es triplemente incompleta: es una visionaria pero tiene una media visión, que "consiste tanto en ver como en no ver" (293); también es el "eco" de Oppiano, el reflejo intelectivo de su hermano; y es la otra mitad de Cemí, el doble-mujer que lo complementa y que, a su vez, la relegará de su estado fragmentario: "Muerto Licario -le dice ella a Cemí-, dueño de las excepciones morfológicas, no puedo yo, una inconsciente infusa, aprovecharme de su herencia, si usted no me insufla el aliento de la imagen" (295). Cemí también es visionario, es el poeta que adquiere el conocimiento por medio de la imagen, pero necesita encontrar lo que le falta en Ynaca, para poder situar la imago en el tiempo por medio de la poesía: "La imago viene a completar la media visión, pues si no existiese la visibilidad de lo increado, no podría existir la cantidad novelada y este diálogo entre usted y yo sería imposible" (295).

La conversación continúa, camino de la casa de Ynaca, bajo la constante evocación a Oppiano Licario. En ese reencuentro José Cemí empieza a sentir la concurrencia de dos fuerzas: la transmisión de las palabras de Ynaca y su presencia femenina que lo introducen en el "círculo regido por Eros" (Varela Jácome 203). El cuerpo, la belleza y el logos de la mujer despiertan el deseo en el joven protagonista. De igual manera, la actitud de José Cemí y su mundo de búsqueda de la poesía -su anhelo por llegar a configurar la imagen, por encontrar un contenido y rebasar su expresión-, lo sitúan ante los ojos de Ynaca como un arquetipo intelectivo, como una fuente de conocimiento. El deseo entonces adquiere una cualidad de reminiscencia, pues José siente que ese simpathos ha sido previsto desde siempre:

Las palabras de Ynaca le despertaron algo semejante al primer descubrimiento, al sentir la sabiduría de Licario pasar por los labios de Ynaca y su belleza. Nunca Cemí había estado tan cerca de la mujer (...) Sintió el deseo, la lucha de la imagen con su sangre, con su piel, con su pelo (...) El deseo de fundirse, de unificarse, saltaba sobre el otro cuerpo cada vez que cerraba los ojos (...) El simpathos, el Eros de la lejanía irradiando en el cuerpo que estaba a su lado, el nexus universal que abatía todas las esclusas (294-296).

Ynaca Eco a su vez, sintiendo la proximidad de Cemí, le refiere lo siguiente:

Ahora comprendo por la cercanía de usted, que nosotros dos, aliados en el reino de la imagen, seríamos la nitroglicerina de las 
transmutaciones, algo así como el descubrimiento de las cadenas nucleares del mundo eidético (...) Cuando no lo tengo a usted a mi lado, la imago no viene en mi ayuda (296).

La conversación termina con la entrega, que hace la mujer al joven protagonista, de la obra de su hermano: Súmula nunca infusa, de excepciones morfológicas. Este texto, según la voluntad de Licario, debía pasar a manos de Cemí, quien queda como depositario de la sabiduría de su mentor. En esa última parte también irrumpe Gabriel Abatón Awalobit, el esposo de Ynaca Eco. Abatón Awalobit es impotente, gracias a él podemos saber cuál es la causa de la tercera carencia de su esposa, pues es incapaz de "penetrar su imagen por su cuerpo, ni con la rapidez del pájaro en el estío, ni con la lentitud de la caída de la hoja" (320). Por ello, esta mujer no podrá conocer lo que le falta en Awalobit -a quien Licario llamaba con sarcasmo "el inaccesible"- sino en Cemí.

\section{IMANTACIÓN DE LOS FRAGMENTOS: LA FUSIÓN DE LAS MITADES}

Los prolegómenos concernientes a la unión corporal entre Ynaca Eco y José Cemí constituyen un verdadero rito iniciático, en el que se mezclan ingredientes de los más variados orígenes, que van desde lo egipcio hasta lo tántrico, pasando por lo afrocubano, para configurar de esta manera un intenso erotismo que adquiere en la obra un carácter esotérico. Los textos hindúes, como el Mahábarata y el Kamasutra, sirven de base a la pareja en el proceso de la unión transfigurativa. Los dos entran en un círculo trazado por Ynaca, donde ella ensaya signos cabalísticos sobre el cuerpo de Cemí, a la vez que se aplican el Nasu de rocío, "siguiendo los consejos zoroástricos" (338). Después de los preámbulos de la alquimia sexual de Ynaca, la fusión de las mitades se perpetúa en el círculo del supremo diálogo. La volupta voluptatis va llenando el cuerpo de José Cemí de destellos y reverberaciones transfigurativas; asimismo, la sacerdotisa va logrando la transmutación deseada, pues su media visión y su fragmentariedad llegan a su término:

En la biblioteca había un pizarrón que Abatón a veces llenaba de ecuaciones o cálculos parabólicos (...) Ante la penetración del aguijón creía proyectarse en la pizarra discos de colores (...) Espirales de color, vibraciones, letras de alfabetos desconocidos (...) Sentía, como 
proyectaba en puntos blancos sobre el pizarrón, la progresión del Lingam como el bastón de Brahma recorriéndola en vibraciones por la columna vertebral (339).

La narración describe de forma insólita la posesión sexual. Se alude a la energía cinética, al placer que se proyecta en figuras geométricas, espirales, círculos que se quiebran, que se fragmentan en partes y multiplican sus radios, al giro de alternancias y mezclas cromáticas. El lenguaje se enriquece y expresa, de manera incomparable, las variaciones placenteras que protagoniza la pareja en el círculo germinador. En unos capítulos más adelante, por medio de una carta que le escribe Fronesis a su amigo, se aclara el sentido y la importancia de la experiencia erótica que vivió José Cemí:

Conocí, por lo profundo a Ynaca (...) Me dijo que ya tú le habías sembrado la semilla. Vas, pues, a ser padre (...) Es decir, si ya con tu amistad con Licario realizaste la unión de la imagen con el conocimiento (...) tu cópula con Ynaca llevaba la imagen al palacio de Elena de Troya unida a las mordidas arenas de la Sibila de Cumas. Albricias, tu cópula con una profunda raíz de símbolo y de realidad transfigurada, ha sido la eficaz (379).

La carta también nos revela en qué consiste la sabiduría sexual de Ynaca: "el conocimiento carnal con ella tiene la voracidad de los complementarios (...) La cópula con ella es como un secreto alquímico, una revelación que se comprende en la quintaesencia" (379-380). Esto era exactamente lo que Cemí defendía en Paradiso con su teoría de la androginia: él la pronunció como un discurso ante sus amigos, pero Ynaca hizo tangible ese ideal al llevarlo a cabo en el círculo del supremo diálogo.

\section{CONSIDERACIONES FINALES}

Teniendo en cuenta lo que hemos expuesto, vemos que a través de las relaciones entre Ynaca Eco y José Cemí se despliega una metafísica sexual que toma fuerza discursiva en Paradiso y se concreta en Oppiano Licario. Dicha metafísica sexual es una metafísica que reivindica una teoría de la androginia, en donde se fundamenta una visión de la sexualidad con características y connotaciones ontológicas, según las leyes del Sistema Poético del Mundo que erige el mismo Lezama. Este Sistema está mediado por la imagen, cuya 
participación en la historia atraviesa las distintas "Eras imaginarias" se configura entonces como una imagen trascendental, que proyecta toda una cosmovisión del mundo lezamiano.

De esta manera, José Cemí se ve llevado hacia la búsqueda de una vía unitiva, defendida por él, para reencontrar la otra mitad que lo complementa y poder alcanzar la infinitud cognoscente por medio de la imago. Sin embargo, lo que le falta solo lo podrá hallar en Ynaca Eco, igualmente incompleta, debido que es una vidente infusa, intuitiva, que tiene el poder de provocar la visión, pero es una visión limitada, fragmentaria. Lo que nos deja por sentado que los dos solo alcanzarán el conocimiento que les falta en la cercanía con el otro. Cemí, en su diálogo transfigurativo con Ynaca, obtiene la visión que conjunta con la imagen y, a su vez, el letargo de ella como vidente llega a su término. Los dos amplían sus posibilidades de ser. Los dos van más allá del mero placer orgánico, del simple acto erótico en sí, pues avanzan hacia el acontecimiento en el que cada uno "pone la mano en el secreto transfigurativo del otro, para lograr la suspensión donde los contrarios se anegan en el Uno Único" (Paradiso 293).

\section{BIBLIOGRAFÍA}

Armas, Emilio. "Introducción a José Lezama Lima”. Lezama Lima, José. Poesía. Madrid: Cátedra, 1992.

Driver, Alice. "La función del erotismo en El acoso de Alejo Carpentier y Paradiso de José Lezama Lima". El Cid XXI (2009): 30-45.

Fossey, Jean-Michel. "Interrogando a Lezama Lima". La Jiribilla de papel 86 (2010): 12-13.

Freud, Sigmund. Introducción al narcisismo y otros ensayos. Trad. Luis López-Ballesteros. Madrid: Alianza, 1973.

Gombrich, Ernst Hans. Imágenes simbólicas. Trad. de Remigio Gómez Díaz. Madrid: Editorial Alianza, 1983.

8 El Sistema Poético del Mundo de José Lezama Lima se desarrolla en varios de sus ensayos: "Introducción a un sistema poético" (1954), "Preludio a las eras imaginarias" (1958), "Introducción a los vasos órficos" (1961), entre otros. El Sistema lezamiano reúne todo aquello que le sirve al hombre para fijar la historia a través de la imagen. Así como los sistemas filosóficos intentan ordenar un conjunto de categorías y valores a través del pensamiento racional en consolidación con la realidad, Lezama Lima erige la estructura de un orden medido por el pensamiento poético que crea un espacio en el que la historia cultural, humana, es "entendida como el ciclo configurador de lo imaginario" (Ortega 513). 
Joyce, James. Retrato del artista adolescente. Trad. Alfonso Donado. Madrid: Premia Editora, 1989.

Lezama Lima, Eloísa. "Para leer Paradiso”. En su edición de Paradiso. Madrid: Cátedra, 1980. Lezama Lima, José. Paradiso. México: Biblioteca Era, 2002. La expresión americana. México: Fondo de Cultura Económica, 1993. Oppiano Licario. Madrid: Cátedra, 1977. “Tratados en La Habana”. Obras Completas II. México: Aguilar, 1977. Introducción a los vasos órficos. Barcelona: Barral Editores, 1971. Las eras imaginarias. Madrid: Editorial Fundamentos, 1971. "Introducción a un sistema poético". Tratados en La Habana. Barcelona: Barral, 1971.

Mann, Thomas. La montaña mágica. Trad. Mario Verdaguer. México: Proxema, 1979.

Musil, Robert. Las tribulaciones del estudiante Törless. Trad. Roberto Bixio y Feliu Formosa. Barcelona: Seix Barral, 1970.

Ortega, Julio. “La biblioteca de José Cemí”. Revista Iberoamericana 92-93 (1975): 510-521. Platón. Diálogos. Trad. de Francisco Larroyo. Argentina: Editorial Porrúa, 1971.

Reyes, Alfonso. La filosofía helenista. México: Fondo de Cultura Económica, 1965.

Sariol, José Prats. "Capítulo VIII: erotismos". Ed. Crítica de Paradiso de Cinto Vitier. Madrid: Colección Archivos, 1998.

Simón, Pedro. Recopilación de textos sobre José Lezama Lima. La Habana: Casa de las Américas, 1970.

Varela Jácome, Benito. Asedios a la literatura cubana: textos y contextos. Universidad Santiago de Compostela: Cátedra de Cultura Cubana Alejo Carpentier, 2002.

Vitier, Cintio. Edición Crítica de Paradiso. La Habana: Letras Cubanas, 1991. 